\title{
Why do local governments resist contracting out?
}

\author{
Paola Garrone, Politecnico di Milano \\ Riccardo Marzano, Politecnico di Milano
}

\begin{abstract}
Local governments are reluctant to contract out public services. This paper shows that resistance to contracting out is not at odds with efficiency. The sample includes all 135 municipalities that were distributing gas in an Italian region when a national reform ended inhouse delivery. Contracting out decisions have been analyzed for the subsequent 12 years through a duration model that admits time dependence and interaction with inter-municipal cooperation. It has been found that opposition to service outsourcing is more likely if scale and managerial efficiency have already been enhanced. Fiscal stress and the activism of citizens are shown not to play a significant role.
\end{abstract}

\section{Keywords}

Contracting out; Efficiency; Municipalities; Inter-municipal cooperation 


\section{Introduction}

Public services have undergone extensive reforms in recent years, particularly at the local level. A prominent role in restructuring efforts has been played by the diffusion of service contracts. During the last two decades, a significant number of cities have outsourced the services for which they are responsible, to private or alternative public providers. Contracting out was devised primarily as a means of improving efficiency through an expansion of the scale of operations, a reduction in management discretion and a better insulation from pressure groups.

Nevertheless, as Section 2 shows, there are signals that contracting out is likely to remain a subordinate delivery mode in local governments. The adoption of service contracts varies to a great extent from country to country and sector to sector. This is not surprising because transaction costs vary according to the market and services characteristics. What is more puzzling is the limited diffusion of service contracts, even in those sectors and countries that are more open towards them. However, reluctance to shift to external delivery is not necessarily a symptom of a poor efficiency-seeking attitude (Section 3). An in-house public provider could in fact have already reached the optimal scale of operations, or strengthened control over managers (through corporatization or partial privatization). In addition, efficiency gains can be pursued through alternative restructuring options, notably intermunicipal joint ventures. Finally, contracting out decisions could be made because of fiscal constraints or local politics, i.e. with little or no relationship with efficiency.

The analysis that is illustrated in the rest of the paper is an attempt to discover the reasons for the reluctance of local governments to contract out, and to assess the efficiency of resistance. The Italian local gas distribution sector has been used as an empirical setting. In 2000, the national Parliament approved a gas sector reform (Section 4). The reform and subsequent acts obliged municipalities to cease direct delivery, and to award the service contract via 
competitive tendering procedures. The dataset includes all of the 135 municipalities that operated the gas distribution service at the date the reform was introduced in Lombardy, a region in Northern Italy with almost 10 million inhabitants. At the end of 2012, the time extensions granted to in-house public delivery had run out, but a highly differentiated landscape emerged. Only $37 \%$ of the municipalities had contracted out the service and, in most cases, the choice had been deferred for as long as possible. The remaining municipalities had openly opposed contracting out (e.g. by appealing to the Antitrust or administrative courts) or had shifted to inter-municipal cooperation.

Italy and, in particular, Lombardy are good candidates for the study of the efficiency of gas delivery choices (Section 4). The gas distribution service is substantially homogeneous from municipality to municipality, due to the technological maturity and nation-wide standards and regulations. This means that transaction costs are unlikely to act as confounding factors, i.e. differences in market and service characteristics can only cause delivery differences to a limited extent. Homogeneous market and service attributes are also likely to level out the market field for potential entrants. At the same time, the municipalities in Lombardy can be argued to be quite heterogeneous in terms of efficiency, owing to the differences in size and governance of the public utilities, and to other determinants (local politics, public budget constraints, civic society).

The main contribution of the paper is that it does a test of the hypothesis that the reluctance of local governments towards contracting out is based upon efficiency reasons. Since resistance to contracting out can translate not only into opposition but also into deferred compliance, we model not only the choice to contract out but also the contract timing (Gonzalez-Gomes and Guardiola 2009; Miralles 2009). Secondly, since some of the motives for contracting out can also justify inter-municipal cooperation (Warner and Hebdon 2001; Hefetz et al. 2012), contracting out municipalities have been distinguished from both cooperating and inactive 
municipalities.

The rest of the paper is organized as follows. Section 2 explains the authors' interest in the resistance of local governments to contracting out by discussing the diffusion of service contracts at the European Union level. Pre-existing literature is reviewed, and research questions are summarized in Section 3. Section 4 highlights the structure and recent evolution of the gas distribution sectors in Italy and in Lombardy, provides information on the data and variables and presents the econometric strategy. The empirical findings are discussed in Section 5. Finally, Section 6 summarizes the main conclusions.

\section{The diffusion of public service contracts in the European Union}

This Section focuses on local governments in European Union (EU) countries with the aim of offering some evidence that public service outsourcing is far from contesting the dominance of in-house provision.

In recent decades, EU countries have increasingly experienced public service outsourcing (reference can be made to Domberger and Jensen 1997, Nemec et al. 2005, Warner and Bel 2008, Johansson 2008). Even though consistent information is lacking about delivery arrangements in the EU countries and over the years, recent information on the new service contracts of EU local governments can be sourced on an online version of the supplement of the Official Journal of the European Union (the so called “Tenders Electronic Daily”). ${ }^{1}$

A descriptive analysis has been carried out for the 2009-2011 period. Evidence on the distribution of new outsourcing contracts for municipal services and in EU countries is summarized in Tables A1 and A2 in the Appendix. Two main findings are here discussed. Before proceeding we emphasize that the comparison between countries should be very

\footnotetext{
${ }^{1}$ In EU countries, the publication of public procurement tenders has been compulsory since 2004, whenever the contract has a value equal to or larger than a given threshold (200,000 Euros in 2012).
} 
cautious because the number of contracts is influenced by the typical size of local authorities that varies over countries.

First, the service contracts are unevenly distributed. Contracting out has been shown to be concentrated on sewage, solid waste and cleaning services (around half of the overall number of contracts). However the diffusion of contracting out is particularly low for public utilities (i.e. water, gas, electricity), public security and rescue services, cultural and sporting services. France has adopted contracting out more than any other EU country. Private outsourcing is also quite frequent in the UK and the Netherlands, but these countries are gradually reducing the use of service contracts. Germany, Italy and Poland are relatively less active, but they are increasingly adopting contracting out.

Second, contracting out seems to be a relatively rare event. A city or urban area with a population of 10,000 , i.e. a medium-sized EU local authority, publishes 0.31 contract notices in 3 years, i.e. around one contract notice every 10 years. Even "outsourcing champions", such as local governments in France or in the Netherlands, are likely to rely extensively on inhouse public delivery. In other words, few municipal services are contracted out in the EU. ome countries and some services seem to be impermeable to contracting out, while others are clearly cutting down on its use. Reference to North-America helps to contextualize the analysis. American and Canadian cities have a significant tradition of outsourcing (Lòpez-deSilanes et al. 1997, Boyne 1998, Warner and Hebdon 2001, Hebdon and Jalette 2008). However, the private provision of municipal services seems to have reached a saturation threshold in the US. The use of service contracts increased from $15 \%$ to $17 \%$ in US cities in the 1992-2007 period (Hefetz et al. 2012).

While differences in outsourcing diffusion between various EU countries and sectors can be framed in terms of differences in transaction costs, the resistance of countries and sectors that are quite advanced in the restructuring path opens the question on the potential advantages of 
public delivery (Section 3), and suggests analyzing a single-country, single-service setting, as has been done in the remaining part of the analysis by considering the Lombardy gas distribution sector (Section 4).

\section{Literature review and research questions}

This Section reviews the economic and policy literature on the motives behind the resistance to contracting out. The research hypotheses are also formulated, in order to design our analysis of the Italian gas distribution case.

Most papers on contracting out assume that local governments rationally compare external v. internal provision choices, and base their assessment primarily on efficiency arguments. Willingness to improve efficiency is not sufficient to contract out, since public delivery is a rational choice if transaction costs between the local government and external providers are large (Williamson 1981 and 1999, Warner and Hebdon 2001, Brown and Potoski 2003). Since transaction costs are related to service and country characteristics, they can be considered as the point of reference to explain why the diffusion of outsourcing differs from country to country and sector to sector, as documented in Section $2 .^{2}$ Nevertheless, transaction costs are less useful to explain another hint of Section 2, i.e. the slowdown of contract outsourcing in some EU countries and sectors. Moreover, they shed little light upon the question why the same service is contracted out by some local governments and not by others, as in the case of Italian gas distribution. Other efficiency determinants have therefore been considered. The role of other restructuring options and other theoretical perspectives are also summarized.

\footnotetext{
2 Contractual costs are mainly due to limited information and uncertainty, which increase with some service characteristics (Levin and Tadelis 2010): difficulty to measure quality performances, necessity to adapt to external circumstances, hold up risks, exposure of citizens to quality problems. On the other hand transaction costs are also shaped by market and citizen characteristics. Countries can differ according to competition (i.e. opportunities to use the private market), cooperation potential (i.e. opportunities to use the "civic" market), and citizen interest in service provision (Hefetz and Warner 2012).
} 


\subsection{Efficiency of resistance to contracting out?}

Contracting out was devised primarily as a means of improving efficiency, i.e. of increasing the scale of operations, of insulating service provision from pressure groups and of reducing management discretion (e.g. Savas 1987, Dubin and Navarro 1988, Lopez-de-Silanes et al. 1997, Bel and Miralles 2003, Dijkgraaf et al. 2003, Sørensen 2007). In a similar way to the most recent works, it is here emphasized that the link between contracting out and cost reduction is contingent to an array of external factors, i.e. public delivery does not imply per se the rejection of efficiency hypothesis. ${ }^{3}$

In-house provision is often characterized by a suboptimal scale of operations, while contracting out is seen as a way of improving productive efficiency by shifting the service to a larger provider. However, if public providers already exploit an efficient size or mix of services, local governments have less compelling motives to contract out (Bel and Miralles 2003, Warner 2011, Warner and Hebdon 2001, Hefetz et al. 2012). Political economy and public choice theories claim that competitive contracting out is a suitable measure to restrain the patronage practices that are typical of public monopolies. Inefficiency of public delivery is due to the lack of market discipline over self-interested politicians (Savas 1987, Lopez-deSilanes et al. 1997, Hirsch and Osborne 2000). While inefficient practices are spurred by pressure groups and lobbies (Boyne 1998, Bel and Fageda 2009), they are hindered by a socially and politically active citizenship (see 3.2 and 3.3). Finally, the literature on contracting out decisions has dealt less frequently with weak governance and managerial dominance. Much emphasis has been put on the shift from public to private provision, but managerial performances can be improved by means of alternative restructuring measures.

\footnotetext{
${ }^{3}$ The determinants of contracting out and competitive bidding in local governments have been the subject of several empirical analyses, particularly for the European utility sectors, e.g. urban waste (Bel and Miralles 2003, Sørensen 2007, Dijkgraaf and Gradus 2008), water (Menard and Saussier 2000, Miralles 2008, Gonzalez-Gomez and Guardiola 2009, Fitch 2007, Carrozza 2010), and urban transport (Cambini and Filippini 2003, YvrandeBillon 2006, Amaral et al. 2009).
} 
For instance, corporatization implies the transfer of control rights from politicians to managers, an arrangement that affects the managers' incentives to perform efficiently (Shleifer and Vishny 1994, Stiglitz 2000), while partial privatization aligns managers to private shareholders' incentives and makes monitoring easier (Gupta 2005). It is therefore not surprising that local governments that have already created municipal corporations or have partially privatized municipal providers have less propensity towards private provision (Aivazian et al. 2005, Bilodeau et al. 2007, Bel and Fageda 2010).

\subsection{Efficiency of inter-municipal joint ventures}

An additional reason why resistance to contracting out is not necessarily inefficient is that local governments can assign the service to inter-municipal joint ventures (IMJVs, mergers between municipal utilities). IMJVs can yield efficiency gains that are comparable with, or even greater than private outsourcing (Warner and Hebdon 2001, Bel and Mur 2009, Hefetz et al. 2012). IMJVs are relatively easy to arrange and can achieve objectives that are consistent with those to which contracting out is directed (Morgan and Hirlinger 1991), e.g. economies of scale beyond a single jurisdiction. ${ }^{4}$ In addition, they constitute a politically attractive alternative because they are compatible with political participation and public accountability (Warner and Hefetz 2002). Finally, according to political economy theories, dispersed public ownership protects the delivery of public services from political interference (Shleifer and Vishny 1994, Boycko et al. 1996). The agency theory instead suggests that the fragmentation of public control that accompanies IMJVs leads to greater agency costs (Dixit 1997).

\footnotetext{
${ }^{4}$ At the same time, local governments experience lower transaction costs, since the risks associated with opportunism of the providers and with goal incongruence between the local government and the provider are minimized (Brown and Potoski 2003).
} 


\subsection{Other determinants of resistance to contracting out}

The resistance of local governments to contracting out can be based on motives that have an indirect or weak relationship with service efficiency, e.g. citizens' voice and participation, political ideology and healthy fiscal conditions.

Politics was traditionally seen as an antecedent of contracting out decisions in several US and European studies (see among others, McGuire et al. 1987, Dubin and Navarro 1988, Lopez de Silanes et al. 1997, Bel and Miralles 2003, Dijkgraaf et al. 2003). An enlarged definition of efficiency in delivery choices has recently been developed. The social choice framework combines different approaches to explain why a deliberation process, which involves citizens, local governments and providers, can ensure socially-superior arrangements (Warner and Hebdon 2001, Warner and Hefetz 2004, Hefetz and Warner 2007 and 2012). In particular, transaction costs and the citizens' voice has been identified as the most significant sources of the shift in preference from contracting out to reverse contracting in US cities over the last few decades (Hefetz and Warner 2007). ${ }^{5}$ Political ideology is another possible determinant. Conservative governments (i.e. linked to right-wing parties) are usually associated with a preference for private service delivery. Finally, contacting out is more likely if local governments have the aim of healing fiscal stress. Service privatization could enhance the public budget, because it weakens cost-increasing practices, such as managerial dominance and political patronage (Lopez-de-Silanes et al. 1997, Kodrzycki 1998, Zullo 2009). This is an efficiency-enhancing effect (see 3.1)). Additionally, if service outsourcing is accompanied by the sale of assets, the incoming cash flows can cause relief from fiscal constraints, an effect that is neutral from an efficiency perspective.

\footnotetext{
${ }^{5}$ The dichotomy between markets and planning, or between contracting out and internal delivery, is replaced by an iterative process in which local governments balance the costs and benefits of competition (supported by new public management), the need to structure markets (supported by the transaction costs theory) and the need to ensure the citizens' voice (supported by new public service and communicative planning).
} 


\subsection{Research hypotheses}

In order to analyze the link between resistance to contracting out and efficiency in the service offer, we focus on productive and managerial efficiency. Unfortunately, there is a lack of good empirical indicators of political patronage at the local level, and the discipline of selfinterested politicians has not been considered.

A) Are local governments more likely to stick to public delivery if they are already efficient in service production (i.e. scale and scope economies have already been exploited)?

B) Are local governments more likely to stick to public delivery if they are already efficient in managing the service (i.e. the public provider has been corporatized or partially privatized)?

In addressing the research questions, we recognize (i) the opportunity to use inter-municipal cooperation rather than contracting out (3.2), and (ii) the role of fiscal stress and social choice (3.3).

\section{Empirical setting and methods}

This Section deals with the empirical case that is analyzed in the remaining parts of the paper and our methodology, i.e. variables, the sample, and econometric models.

\subsection{The gas distribution service in Italy and Lombardy}

The empirical setting is that of the gas distribution in Lombardy, a region in North Italy. Lombardy has been chosen as the case study, because it is the largest regional natural gas market in Italy. In 2012, 4.8 million customers were supplied with 8,992 million mc of natural gas (i.e. roughly one fourth of the national supply), through distribution networks that cover a 
distance of $47,033 \mathrm{~km}$ and which reach nearly all the municipalities. ${ }^{6}$ At the same time, the collection of detailed information for the whole country has proved to be difficult.

Most municipalities in the North and in Central Italy have traditionally ensured the distribution of gas for cooking and heating through in-house municipal delivery, but increasing concerns about the efficiency of public delivery have been expressed since the mid-Eighties (Bognetti and Robotti 2003). Soft budget constraints and the fragmentation of operations over many small municipal enterprises or departments have been acknowledged to be the major causes of inefficiency. ${ }^{7}$

In 2000, the national Parliament issued a law that implemented the 1998 EU Directive on the internal gas market. Gas distribution and transport were unbundled from gas supply and retail, which were opened up to new entrants (Law Decree no. 164 of 2000). The in-house distribution of gas, via municipal departments or enterprises, had to cease by 2005 , while competitive awarding of service contracts was made compulsory (Dorigoni and Portatadino 2009). ${ }^{8}$ The deadline for service outsourcing was later put off until 2007 , and time extensions of a few years were granted under certain conditions, but all time extensions were expected to expire by the end of 2012. Nevertheless, only a very limited number of small municipalities had actually contracted out the distribution service by that date (i.e. in 2011, the service had only been outsourced in 808 out of 6,147 municipalities). Some cities have appealed to administrative courts or the Antitrust, requesting a suspension of the obligation to contract

\footnotetext{
${ }^{6}$ The data for this sub-section have been sourced from annual reports, publications and statistics that are published by the Italian energy regulatory authority of energy (http://www.autorita.energia.it/it/index.htm) and the Italian association of municipal utilities (http://www.federutility.it/).

${ }^{7}$ To counteract excessive spending by local governments, the national Parliament passed a law in 1998, that obliged local governments to meet public budget targets, in coherence with the European Union Stability Pact (art. 28 of Law 448/1998).

${ }^{8}$ Competitive procedures to contract out the service operation, or to select a private partner, were introduced in 1994 in the water sector (Carrozza 2010), and were extended to all local services in 2000 (Bognetti and Robotti 2007).
} 
out. Table 1 reports other information about the sector, especially on ownership arrangements. The sector included 775 private or public utilities in 2000, but only 262 utilities ran gas distribution in 2011. The sector has been concentrating to a significant degree, but municipal ownership has not yet been driven out (Table 1).

Table 1 - Gas distribution industry in Italy: ownership arrangements, 2011

\begin{tabular}{|l|cc}
\hline & Number of enterprises & Number of municipalities $^{\wedge}$ \\
\hline Total & 262 & 6,147 \\
\hline Private ownership* & 125 & 4,978 \\
Municipal ownership $^{\circ}$ & 137 & 1,169 \\
\hline
\end{tabular}

Source: Personal elaboration of the annual reports and statistics of the Italian energy regulatory authority (http://www.autorita.energia.it/it/index.htm) and the Italian association of municipal gas, electricity and water utilities (http://www.federutility.it/).

Notes. $\wedge^{\wedge}$ : The counts include only municipalities that are reached by gas distribution networks. *: The service is offered by a firm whose control rights are held by private investors; consortia of private firms are included. ${ }^{\circ}$ : The service is offered by a municipal department or an enterprise whose control rights are held by one or more municipalities.

As far as Lombardy is concerned, the municipalities had control rights over 135 enterprises in 2000. In 2012, the number of municipal enterprises was much smaller, i.e. 34 (-75\%), but this sector concentration does not mean that municipal ownership had been marginalized. Deferred compliance and opposition to contracting out had also touched Lombardy (Section 4.2). Additionally, IMJVs had become relevant (see Section 4.2). Finally, municipal gas distributors had acquired a few middle-sized private operators, and had won competitive procedures in other cities. As a result, the number of cities that are served by a municipal utility have increased from 287 to $446(+55 \%)$.

In short, the Lombardy gas distribution can be considered an appropriate testing ground for the research questions. First, the delivery reform can be argued to act as an exogenous shock, which makes the econometric analysis easier. Second, the productive and managerial efficiency of the delivery arrangements can be tested, other things being equal, because the municipalities in Lombardy are highly different in terms of both size and governance patterns, and political and fiscal dimensions (Section 4.2). Finally, transaction costs can be left out of 
the analysis, because the gas technologies and operating practices are mature and standardized, and because the tariffs and quality are determined by a national regulator.

\subsection{Sample and variables}

The dataset accounts for the population of the municipalities in Lombardy that owned and controlled a gas distributor in 2000, i.e. 135 municipalities that were observed from 2001 to 2012. ${ }^{9}$ The sample distribution over the provinces and population is shown in Table A3 in the Appendix. Thirty-four and 32 cases out of 135 are located in the Milan and Bergamo provinces respectively, while the remaining cases are located in the other 10 provinces. Most of the municipalities that own a gas distributor are small or medium sized (i.e. 86 municipalities have smaller populations than 15,000 inhabitants, and the population only exceeds 50,000 inhabitants in 12 sample municipalities).

Table 2 shows the time distribution of contracting out and inter-municipal joint ventures (IMJVs) over the sampled municipalities. In 2012, twelve years after the introduction of the reform (Section 4.1), a differentiated landscape emerged. A first group of cities had contracted out the distribution service (50 out of 135), although the outsourcing dates differ to a great extent. The remaining municipalities have not yet complied with the reform ( 85 out of 135), mainly because they have opposed contracting out (for instance by appealing to the Antitrust authority or administrative courts). Seventy out of 135 municipalities had merged the gas distribution operations with other municipalities during the 2001-2012 period. Intermunicipal cooperation shows a high correlation with opposition (i.e. 64 resisting municipalities out of 85 had also been involved in inter-municipal mergers). Contracting out and inter-municipal cooperation events are concentrated in the early reform years. In recent

\footnotetext{
${ }^{9}$ The public internal delivery concerned 140 municipalities, but it was not possible to identify five small municipalities that hold control rights of five very small distributors.
} 
years, the municipalities seem to have played for time, perhaps because of the possibility of having time extensions and due to legislative and regulatory instability. The information on the identity of the Lombardy gas distributors has been collected from the yearly records of the Italian energy regulatory authority (AEEG), while the information on utility ownership, contracting out events and IMJVs has been collected from websites and annual utility reports, and has been cross-validated through the yearbooks of the Italian association of municipal utilities and newspapers articles.

Table 2 - Contracting out and inter-municipal joint ventures over the 2001-2012 period

\begin{tabular}{|l|ccccccc|}
\hline & 2001 & 2002 & 2003 & 2004 & 2005 & 2006 & \\
\hline Contracting out & 0 & 17 & 16 & 0 & 1 & 0 & \\
Inter-municipal joint ventures & 2 & 22 & 13 & 1 & 8 & 11 & \\
\hline & 2007 & 2008 & 2009 & 2010 & 2011 & 2012 & Total \\
\hline Contracting out & 0 & 2 & 6 & 2 & 6 & 0 & 50 \\
\hline Inter-municipal joint ventures & 7 & 4 & 2 & 0 & 0 & 0 & 70 \\
\hline
\end{tabular}

Source: Personal elaboration of the yearly lists of the Italian energy regulatory authority (http://www.autorita.energia.it/it/index.htm), of the information and annual reports published on utility websites, and data from the yearbooks of the Italian association of municipal utilities (http://www.federutility.it/).

Table 3 - List of variables and definitions

\begin{tabular}{|c|c|}
\hline & Definition \\
\hline Size & Overall population of all served municipalities $[00,000]$ \\
\hline OthServ & Binary variable $=1$ if the utility also operates water or electricity services \\
\hline Corp & Binary variable $=1$ if the utility is a corporation \\
\hline MunConc & Index of municipal ownership concentration \\
\hline Private & Binary variable $=1$ if there are private shareholders \\
\hline $\mathrm{D}_{\mathrm{ES}}$ & Binary variable $=1$ if the utility size is greater than the MES \\
\hline FiscStress & Ratio between Current Expenditures and Current Revenues in the local public budget \\
\hline Left & Binary variable $=1$ if the local government is affiliated to left-wing parties \\
\hline CivLis & Binary variable $=1$ if the local government is affiliated to local civic parties \\
\hline ElecYear & Binary variable $=1$ for years of local election \\
\hline ElecPart & Local voter turnout in the last regional election \\
\hline Mountain & Binary variable $=1$ if the municipality is located in a mountain area \\
\hline
\end{tabular}

The independent variables have been grouped on the basis of the contracting out determinants that were identified in Section 3, i.e. productive efficiency, managerial efficiency, social choice, ideology and fiscal stress. Controls have been added. The efficiency indicators have 
been computed using the characteristics of the gas distributors, while the other indicators have been measured focusing on the municipality. The variables are listed in Table 3.

The degree to which utilities are already productively efficient depends on the degree to which the scale and scope economies are exploited. Size refers to the population of the served municipalities. ${ }^{10}$ MES is the minimum efficient scale that was established according to the econometric literature on cost functions in Italian gas distribution and in particular according to Erbetta and Rappuoli (2008), who estimated MES to be equal to 65,000 customers or 195,000 inhabitants. DES is a dummy variable that takes on a value of 1 when the utility size is greater than the MES. The cross product between DES and (Size-MES) is included in the model along with Size to allow the scale economies to vary with the size. OthServ is a dummy that is set equal to 1 if the gas distributor also operates water or electricity services, and it models economies of scope. The degree to which managerial discretion is limited, i.e. managerial efficiency is already satisfactory, is represented by three governance characteristics. Corp and Private are two dummy variables. Corp is set equal to 1 when the gas distributor is a corporation, and Private is set equal to 1 when stockholding is partially private. MunConc measures the extent to which municipal ownership is concentrated through a Hirsh-Herfindal index, with focus on municipal ownership: it is set equal to 1 if there is only one municipal owner; it tends to 0 if the IMJV includes several small municipal owners.

The alternative determinants of contracting out have been grouped into three categories: fiscal stress, ideology and social choice. FiscStress refers to the ratio between current expenditures and current revenues. Ideology is captured by two dummy variables: Left takes on a value of 1 when the local government is progressive, i.e. affiliated to left-wing parties; CivLis takes on a value of 1 when a civic party or movement governs the city, i.e. a party that has no official connection to traditional national parties and which campaigns about local issues. The

\footnotetext{
${ }^{10}$ The population of the served area seems to be an acceptable proxy since the gas consumption per user is quite homogeneous in Lombardy.
} 
political (and social) activism of citizens is summarized by ElecPart, the turnout in the regional election. ${ }^{11}$ Finally, two control variables have been added on. ElecYear takes on a value of 1 in the year of the local election. Mountain is set equal to 1 when the city is officially classified as mountainous, a circumstance that may alter the scale and scope economies. $^{12}$

The descriptive statistics and data sources are reported in Table 4. By definition when a municipality contracts out the service, it exits from the analysis of the resistance of local governments. Therefore, the sample panel is unbalanced over time, and amounts to 1,243 observations.

Table 4 - Descriptive statistics and data sources of the independent variables

\begin{tabular}{|l|ccccc|c|}
\hline & Obs & Mean & Sd & Max & Min & Sources \\
\hline Size & 1243 & 1.352 & 3.019 & 25.128 & 0.003 & \\
OthServ & 1243 & 0.485 & 0.499 & 1 & 0 & Information and annual reports \\
Corp & 1243 & 0.858 & 0.349 & 1 & 0 & published on utility websites \\
Private & 1243 & 0.167 & 0.373 & 1 & 0 & \\
MunConc & 1243 & 0.657 & 0.386 & 1 & 0.011 & Personal elaboration on Erbetta \\
D $_{\text {ES }}$ & 1243 & 0.142 & 0.350 & 1 & 0 & and Rappuoli (2008) \\
FiscStress & 1243 & 0.942 & 0.067 & 1.378 & 0.596 & \\
Left & 1243 & 0.268 & 0.443 & 1 & 0 & Databases of the Italian Ministry \\
CivLis & 1243 & 0.295 & 0.456 & 1 & 0 & of the Interior (Local Finance and \\
ElecYear & 1243 & 0.194 & 0.396 & 1 & 0 & Elections) \\
ElecPart & 1243 & 0.735 & 0.053 & 0.857 & 0.571 & Database of the Italian Ministry of \\
Mountain & 1243 & 0.188 & 0.391 & 1 & 0 & Economic Development \\
\hline
\end{tabular}

\subsection{Models}

Most of previous studies have used cross-sectional data to model contracting out decision. The dependent variable was either a binary choice variable (i.e. internal v. external delivery of

\footnotetext{
${ }^{11}$ Regional rather than local election turnout has been chosen to establish fundamental political participation, irrespectively of contingent city-specific effects.

${ }^{12}$ This variable is similar to the rural status of municipalities in the US (see Hefetz and Warner 2012).
} 
given services; e.g. Menard and Saussier 2000, Bel and Miralles 2003, Dijkgraaf et al. 2003, Walls et al. 2005, Tavares and Camoes 2007), or a limited continuous variable (i.e. proportion of the outsourced services; Ferris 1986, Morgan et al. 1988, Greene 1996, Warner and Hefetz 2008). Nevertheless, the delivery choice can relate to historical rather than contemporary measures of city or service characteristics (Boyne 1998), and time matters for contracting out decisions. This has only been recognized recently. Joassart-Marcelli and Musso (2005) have used panel data to track changes in public service delivery over a 15 -year time period, considering 11 municipal services. Gonzalez-Gomes and Guardiola (2009) and Miralles (2009) have used duration models to explain the decision to contract out water services in Spain.

Since opportunity existed of following the Lombardy municipalities over a period of 12 years, it has been quite natural to model them using a duration model that can handle the whole range of attitudes towards contracting out, i.e. early externalization, deferred compliance and opposition till the deadline (Sections 4.1 and 4.2). The hazard rate $\lambda$ is the probability of contracting out at time $t$, conditional to internal delivery up to $t$, i.e. the length of time that a municipality has spent before contracting out the gas distribution. The present observations are on a yearly basis, and has been made use of discrete time duration models. The hazard rate for municipality $i$ observed up to time $j$ is as follows:

$$
\lambda_{i j}\left(j, X_{i j}\right)=P\left(T_{i}=j \mid T_{i} \geq j, X_{i j}\right) .
$$

$T_{i}$ is the discrete time survival variable of the municipality which is modeled as the combination of two functions, i.e. dependence on time and the effect of the covariates $X_{i j}$ on the decision to contract out, after having controlled for time dependence. The impact of covariates is modeled through a binary probit model. ${ }^{13}$ Time dependence $T$ is the baseline

\footnotetext{
13 An admissible distribution function was needed for the hazard rates. An obvious choice was the standard normal distribution, which makes it possible to estimate the coefficients using a probit model. Since there are
} 
hazard function, i.e. the probability of contracting out in the absence of covariates. In this case, time dependence can distinguish local governments' decisions from confounding factors (e.g. changes in nation-wide regulations, exhaustion of targets, favorable economic climate, learning about service contracts). In order to obtain time dependence flexibility, cubic splines, i.e. a smoothed version of time dummies, have been used (Beck et al. 1998).

The authors are well aware of the fact that local governments also consider inter-municipal joint ventures (IMJVs; Sections 4.1 and 4.2). The correlation between IMJVs and contracting out is equal to -0.824 , i.e. local governments seem to perceive them as alternative but interdependent restructuring measures. Therefore, a two-equation duration model has been used, and a so called Mixed model has been estimated (Roodman 2009). The first equation is a contracting out duration model and the second equation is a duration model of the decision to cooperate with other municipalities. ${ }^{14}$ An alternative approach to the simultaneity between IMJV and contracting out decisions is offered by an Instrumental Variable (IV) model. Some explanatory variables of the contracting out model, i.e. Size, $D_{E S}$ and MunConc, are potentially impacted by the choice to enter an IMJV, a decision that is highly correlated to the decision to contract out the service. In order to cope with the kind of endogeneity here mentioned, the endogenous variables have been instrumented with the same variables measured at the beginning of the period. IV estimates have been used to test the endogeneity of the variables and to check the robustness of the Mixed model estimates.

small differences between the probit and other specification in this context (Beck et al. 1998), it was decided to use a probit duration model, which allows the potential of the Stata software package to be exploited for the mixed models (Roodman 2009).

${ }^{14}$ Each of the equations in the Mixed Model is a discrete time duration equation that shares with the other one all the explanatory variables except those that refer to the baseline hazard function, which are different in the two equations (Roodman 2009). 


\section{Empirical findings}

The results of the empirical analysis on contracting out are illustrated in this Section.

Table 5a and Table 5b report the Mixed model estimates, i.e. the contracting out and intermunicipal cooperation equations in three different specifications. The ETD model includes variables that represent incentives to search for productive and managerial efficiency, and time dependence. The EOD model also includes determinants other than efficiency, but not time dependence. The ETDOD model includes all the covariates and time dependence. The discussion on the empirical findings will focus on models with time dependence, because the inclusion of time dependence was tested through Wald tests that rejected exclusion (i.e. the $\chi^{2}(3)$ statistics was invariably estimated to be different from 0 with a $99 \%$ confidence level). The EOD equation estimates have only been provided for comparison purposes. The contracting out equation can exploit the whole sample, which includes 1,243 observations (i.e. 135 municipalities and 12 years, but the time series are right-censored when the service is contracted out). Since inter-municipal cooperation, by definition, can occur only before contracting out, the IMJV equation is estimated on a smaller sample, i.e. 725 observations. Nevertheless, the two equations has been jointly estimated (i.e. there is a common maximum likelihood function). The estimates have been obtained using the Stata software package, version 12.1. Finally, three and four spline coefficients have resulted to be necessary to fit the time dependence of contracting out and inter-municipal respectively. For the sake of brevity, the Instrumental Variable duration model estimates are not reported here but are available upon request from the authors. They suggest that the endogeneity of Size, $D_{E S}$ and MunConc is not a serious issue (i.e. the residual correlations between the instrumental equations and the duration model of contracting out are not significantly different from zero). 
Table 5a - Estimates of the Mixed duration models: Contracting out equation

\begin{tabular}{|c|c|c|c|}
\hline \multirow[b]{2}{*}{ Independent Variables } & \multicolumn{3}{|c|}{ Equation 1 - Contracting out } \\
\hline & $\begin{array}{l}\text { ETD Model: Efficiency } \\
\text { and time dependence }\end{array}$ & $\begin{array}{l}\text { EOD Model: } \\
\text { Efficiency, and other } \\
\text { determinants }\end{array}$ & $\begin{array}{c}\text { ETDOD Model: } \\
\text { Efficiency, time } \\
\text { dependence and other } \\
\text { determinants }\end{array}$ \\
\hline Size & $\begin{array}{c}-0.471 * * \\
(-1.99)\end{array}$ & $\begin{array}{l}-0.382^{*} \\
(-1.92)\end{array}$ & $\begin{array}{c}-0.431 * \\
(-1.81)\end{array}$ \\
\hline$D_{E S} *($ Size-MES) & $\begin{array}{l}0.360 \\
(1.18)\end{array}$ & $\begin{array}{l}0.247 \\
(0.89)\end{array}$ & $\begin{array}{l}0.294 \\
(0.93)\end{array}$ \\
\hline OthServ & $\begin{array}{l}-0.175 \\
(-0.96)\end{array}$ & $\begin{array}{l}-0.232 \\
(-1.33)\end{array}$ & $\begin{array}{l}-0.190 \\
(-1.05)\end{array}$ \\
\hline Corp & $\begin{array}{c}-1.500 * * * \\
(-5.23)\end{array}$ & $\begin{array}{c}-1.344 * * * \\
(-5.94)\end{array}$ & $\begin{array}{c}-1.627 * * * \\
(-5.53)\end{array}$ \\
\hline Private & $\begin{array}{l}0.157 \\
(0.66)\end{array}$ & $\begin{array}{l}0.169 \\
(0.78)\end{array}$ & $\begin{array}{l}0.157 \\
(0.65)\end{array}$ \\
\hline MunConc & $\begin{array}{l}-0.096 \\
(-0.29)\end{array}$ & $\begin{array}{l}-0.139 \\
(-0.43)\end{array}$ & $\begin{array}{l}-0.071 \\
(-0.20)\end{array}$ \\
\hline FiscStress & & $\begin{array}{l}0.469 \\
(0.37)\end{array}$ & $\begin{array}{l}0.729 \\
(0.53)\end{array}$ \\
\hline Left & & $\begin{array}{c}-0.601 * * * \\
(-2.67)\end{array}$ & $\begin{array}{c}-0.637 * * \\
(-2.42)\end{array}$ \\
\hline CivLis & & $\begin{array}{l}0.004 \\
(0.02)\end{array}$ & $\begin{array}{l}0.072 \\
(0.38)\end{array}$ \\
\hline ElecYear & & $\begin{array}{l}-0.221 \\
(-0.86)\end{array}$ & $\begin{array}{l}-0.255 \\
(-1.01)\end{array}$ \\
\hline ElecPart & & $\begin{array}{c}-4.310^{* *} \\
(-2.45)\end{array}$ & $\begin{array}{l}-1.921 \\
(-0.90)\end{array}$ \\
\hline Mountain & & $\begin{array}{l}-0.215 \\
(-1.00)\end{array}$ & $\begin{array}{l}-0.117 \\
(-0.55)\end{array}$ \\
\hline Cons & $\begin{array}{c}-1.465 * * * \\
(-3.52) \\
\end{array}$ & $\begin{array}{l}2.448 \\
(1.28)\end{array}$ & $\begin{array}{l}-0.679 \\
(-0.32) \\
\end{array}$ \\
\hline No. of observations & 1243 & 1243 & 1243 \\
\hline Spline coefficients & $\begin{array}{c}0.351 * * * \\
(2.69) \\
-1.122 * * \\
(-2.29) \\
2.671 * * \\
(2.37) \\
\end{array}$ & & $\begin{array}{c}0.444 * * * \\
(3.15) \\
-1.463 * * * \\
(-2.68) \\
3.335 * * * \\
(2.71) \\
\end{array}$ \\
\hline Wald chi2(k) & $81.57(k=9)$ & $123.22(k=12)$ & $105.15(k=15)$ \\
\hline$p>$ chi2 & 0.000 & 0.000 & 0.000 \\
\hline Atanhrho_12 & $\begin{array}{c}-1.218 * * * \\
(-2.71) \\
\end{array}$ & $\begin{array}{c}-1.703 * * * \\
(-13.18) \\
\end{array}$ & $\begin{array}{c}-2.444 * * * \\
(-5.36)\end{array}$ \\
\hline
\end{tabular}

Notes. t statistics in parentheses; $* * *, * *, *: 99 \%, 95 \%$ and $90 \%$ significance levels in a two-tail test. 
Table 5b - Estimates of the Mixed duration models: Inter-municipal cooperation equation

\begin{tabular}{|c|c|c|c|}
\hline \multirow[b]{2}{*}{ Independent Variables } & \multicolumn{3}{|c|}{ Equation 2-IMJV equation } \\
\hline & $\begin{array}{l}\text { ETD Model: Efficiency } \\
\text { and time dependence }\end{array}$ & $\begin{array}{l}\text { EOD Model: } \\
\text { Efficiency, and other } \\
\text { determinants }\end{array}$ & $\begin{array}{c}\text { ETDOD Model: } \\
\text { Efficiency, time } \\
\text { dependence and other } \\
\text { determinants }\end{array}$ \\
\hline Size & $\begin{array}{l}0.455^{* *} \\
(2.16)\end{array}$ & $\begin{array}{c}0.631 * * * \\
(3.22)\end{array}$ & $\begin{array}{l}0.606^{* * *} \\
(2.70)\end{array}$ \\
\hline$D_{E S}{ }^{*}($ Size-MES $)$ & $\begin{array}{c}-0.464 * * \\
(-2.06)\end{array}$ & $\begin{array}{c}-0.641 * * * \\
(-3.04)\end{array}$ & $\begin{array}{c}-0.627 * * * \\
(-2.64)\end{array}$ \\
\hline OthServ & $\begin{array}{l}0.097 \\
(0.58)\end{array}$ & $\begin{array}{l}0.078 \\
(0.47)\end{array}$ & $\begin{array}{l}0.118 \\
(0.64)\end{array}$ \\
\hline Corp & $\begin{array}{c}-0.589 * * * \\
(-2.88)\end{array}$ & $\begin{array}{l}-0.312 * \\
(-1.92)\end{array}$ & $\begin{array}{c}-0.631 * * * \\
(-3.16)\end{array}$ \\
\hline Private & $\begin{array}{l}-0.429^{*} \\
(-1.74)\end{array}$ & $\begin{array}{l}-0.310 \\
(-1.38)\end{array}$ & $\begin{array}{l}-0.349 \\
(-1.40)\end{array}$ \\
\hline MunConc & $\begin{array}{l}-0.127 \\
(-0.40)\end{array}$ & $\begin{array}{l}-0.160 \\
(-0.55)\end{array}$ & $\begin{array}{l}-0.197 \\
(-0.58)\end{array}$ \\
\hline FiscStress & & $\begin{array}{l}0.298 \\
(0.31)\end{array}$ & $\begin{array}{l}1.275 \\
(0.99)\end{array}$ \\
\hline Left & & $\begin{array}{l}0.253^{*} \\
(1.81)\end{array}$ & $\begin{array}{l}0.198 \\
(1.20)\end{array}$ \\
\hline CivLis & & $\begin{array}{l}0.186 \\
(1.09)\end{array}$ & $\begin{array}{l}0.211 \\
(1.11)\end{array}$ \\
\hline ElecYear & & $\begin{array}{l}-0.123 \\
(-0.71)\end{array}$ & $\begin{array}{l}-0.142 \\
(-0.79)\end{array}$ \\
\hline ElecPart & & $\begin{array}{l}1.403 \\
(1.15)\end{array}$ & $\begin{array}{l}-0.478 \\
(-0.23)\end{array}$ \\
\hline Mountain & & $\begin{array}{l}0.518^{* * * *} \\
(3.04)\end{array}$ & $\begin{array}{c}0.555^{* * *} \\
(2.92)\end{array}$ \\
\hline Cons & $\begin{array}{c}-2.047 * * * \\
(-4.78)\end{array}$ & $\begin{array}{c}-2.675^{*} \\
(-1.82) \\
\end{array}$ & $\begin{array}{l}-3.160 \\
(-1.52)\end{array}$ \\
\hline $\begin{array}{l}\text { No. of observations - } \\
\text { Equation } 2\end{array}$ & 725 & 725 & 725 \\
\hline Spline coefficients & $\begin{array}{c}0.560 * * * \\
(3.91) \\
-3.912 * * * \\
(-2.80) \\
8.851 * * * \\
(2.59) \\
-14.71 * * \\
(-2.39) \\
\end{array}$ & & $\begin{array}{c}0.608 * * * \\
(3.99) \\
-4.143 * * * \\
(-2.88) \\
9.217 * * * \\
(2.65) \\
-14.77 * * \\
(-2.33) \\
\end{array}$ \\
\hline $\begin{array}{l}\text { Wald chi2(k) } \\
p>\text { chi2 }\end{array}$ & $\begin{array}{c}81.57(k=9) \\
0.000\end{array}$ & $\begin{array}{c}123.22(k=12) \\
0.000\end{array}$ & $\begin{array}{c}105.15(k=15) \\
0.000\end{array}$ \\
\hline Atanhrho_12 & $\begin{array}{c}-1.218 * * * \\
(-2.71) \\
\end{array}$ & $\begin{array}{c}-1.703 * * * \\
(-13.18) \\
\end{array}$ & $\begin{array}{c}-2.444 * * * \\
(-5.36) \\
\end{array}$ \\
\hline
\end{tabular}

Notes. t statistics in parentheses; ${ }^{* * *},{ }^{* *}, *: 99 \%, 95 \%$ and $90 \%$ significance levels in a two-tail test. 


\subsection{Analysis of the research questions}

The efficiency of resistance toward contracting out is the focal issue of the present analysis. In order to test the research questions, the coefficient estimates from the contracting out equations are discussed (Table 5a). It should be recalled that the duration model can be decomposed into two parts (Section 4.3): a probit model without time dependence, i.e. the impact of independent variables on the contracting out probability at any time; time dependence, i.e. the variation of contracting out probability over time if the independent variables are held constant. In what follows, attention is focused on the impact of the covariates, while the time dependence of contracting out is discussed in another sub-section (5.2).

As far as research question (A) is concerned, it has been tested whether contracting out is less likely to occur in municipalities that own larger gas distributors (scale economies) or utilities operating gas distribution and other network services (economies of scope). It has also been checked whether the incentives to outsource the service change when the utility reaches the minimum efficient scale of the sector (MES, almost 200,000 inhabitants). The Size coefficient is different from zero and negative at a $10 \%$ level of significance in the most comprehensive model (ETDOD, third column in Table 5a), and at the 5\% or $10 \%$ levels in the other models. The sum of the Size and $D_{E S} *($ Size-MES) coefficients is not significantly different from 0 (e.g. p-value of the $\chi^{2}(1)$ test equal to 0.431 , ETDOD model, Table 5a). Municipalities that are served by small municipal utilities have been found to be more likely to contract out, a result that is coherent with the findings of other empirical studies (McGuire et al. 1987; Hirsch 1995; Bel and Miralles 2003; Dijkgraaf et al. 2003). The outsourcing probability decreases as the size approaches MES, but then it reaches a saturation threshold, i.e. if the size grows beyond MES, the outsourcing probability no longer changes. Large utilities can counterbalance the lack of productive efficiency gains from contracting out with other 
advantages. For instance, some analyses have found that larger municipalities are more likely to privatize (Ferris 1986; Greene 1996; Gonzalez-Gomes and Guardiola 2009), because they can average transaction costs over a larger population. The willingness to preserve the economies of scope has not been found to play a role (the OthServ coefficient is not significant in any of the three models, Table 5a). However, it has not been possible to compare this finding with previous analyses, as none has been found that considered multiutilities cases. It has been concluded that resistance to contracting out, in the case of Italian gas distribution, could have been caused by an emphasis of the municipalities on productive efficiency. Local governments are more likely to stick to public delivery if they have already exploited scale economies, i.e. if they have already reached the minimum efficient scale in service operation. The empirical results of the IV model also confirm that contracting out decisions made by municipalities are aimed at the exploitation of scale economies, even though the significance of the coefficients is weaker.

Contracting out benefits include an improvement in managerial efficiency (research question (B)). However, the discretion of utility managers can be reduced by other restructuring measures, such as corporatization or partial privatization (i.e. stockholding sale without transferring control rights to the private sector). Research question (B) test has focused on the Corp and Private coefficients. The impact of corporatization on the decision to contract out gas distribution is different from 0 and negative at the $1 \%$ significance level (Table 5a, all models). The Private coefficient instead is never significant. The incremental advantages of contracting out are thus relatively small if the administration department has already been changed in a company. Corporatized utilities resemble modern corporations, where managers are easier to monitor than bureaucrats (Aivazian et al. 2005; Bilodeau et al. 2007; Cambini et al. 2011). The reason why partial privatization does not play a comparable role has remained unsolved, but it should be recalled that corporatization needs to be necessarily implemented 
before partial privatization. If so, the two coefficients can interact. The concentration of municipal ownership, as represented by MunConc, does not affect the probability outsourcing significantly, but there are diverging theories on its impact on efficiency (3.2). It is here concluded that local governments are more likely to stick to public delivery if the governance of service provision has already been tightened through corporatization. The empirical results of the IV model have provided similar empirical evidence.

\subsection{Time dependence}

The three Mixed models appear to be well specified, according to the Wald test reported at the bottom of both Tables $5 \mathrm{a}$ and $5 \mathrm{~b}$. Furthermore, unobserved heterogeneity or frailty, i.e. the hazard related to residual differences between municipalities, has been tested, and has not been found significant at the standard confidence levels. ${ }^{15}$

An additional reason that makes us fairly confident in the results that have been discussed so far is provided by the analysis of time dependence. First, the two research questions have been confirmed after having removed the time trend of contracting out from the probit estimates in the ETD and ETDOD models (Table 5a). As a result, the acceptation of the "efficiency hypothesis" on resistance towards contracting out is not biased by time-specific confounding effects (e.g. regulation changes or the economic cycle). Second, the present estimates can be used to simulate the time trend of contracting out, in order to carry out an expost comparison with the real evolution of the gas distribution sector in Lombardy (Section 4.1). Figure 1 reports the time trend that has been simulated from the ETDOD model in Table 5a. The baseline hazard function has been assigned the spline coefficients and the count of years as time variables. All the independent variables have been set to their mean values, in order to have realistic values of the probability of contracting out (i.e. they only shift the time

\footnotetext{
${ }^{15}$ The likelihood ratio test has rejected the null hypothesis that the heterogeneity variance is zero for contracting out $(\mathrm{p}$-value $=0.112)$ and inter-municipal cooperation ( $\mathrm{p}$-value $=0.132)$.
} 
trend). The graph in Figure 1 represents the evolution of the probability of contracting out that a "mean" Lombardy municipality would have experienced over time, on the basis of the reform of gas distribution delivery and other year-specific effects, if the efficiency, fiscal and political variables did not have any influence. It appears to be consistent with at least two aspects of the dynamics that have been summarized in Section 4.1. In 2005, a regulatory change postponed the expiry dates of the contracts in force by two years, and slowed down the overall process. The simulated time trend has captured the effect of the shift in the reform deadline quite precisely, as can be seen from the 2005-2008 decrease. Apart from the slowdown caused by the regulation change, the simulated contracting out probability kept rising over the whole period, which is coherent with the obligation to award a new gas distribution service contract by 2012 .

Figure 1 - Simulated time dependence of the contracting out probability, ETDOD model

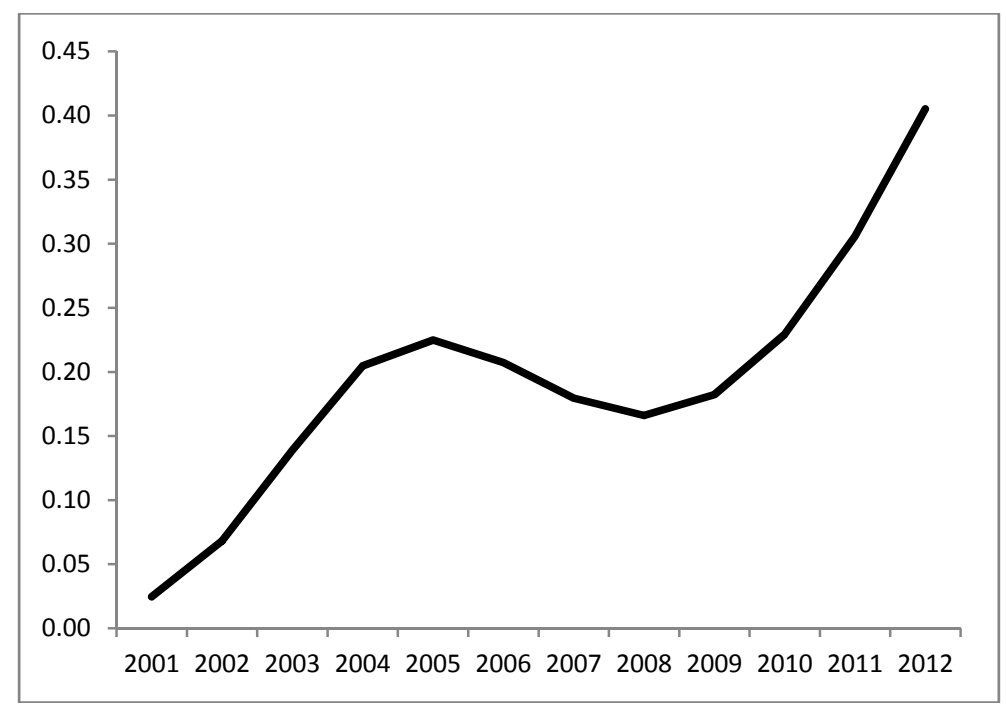

\subsection{Other determinants of contracting out}

The other possible determinants of contracting out, i.e. fiscal stress, ideology, political and social participation of citizens, are now examined. The only variable that has been shown to affect the decision to contract out gas distribution in a robust way is ideology. The Left coefficient is significantly different from 0 and negative at standard significance levels in both 
of the contracting out models that encompass determinants different from efficiency (EOD and ETDOD, last two columns in Table 5a). The local governments that are affiliated to leftwing parties are more likely to resist contracting out. This result is consistent with previous analyses concerning both the US and European countries (Dubin and Navarro 1988; Dijkgraaf et al. 2003; Walls et al. 2005; Zullo 2009). The political and social activism of citizens, as measured by ElecPart, i.e. the local turnout of voters, has been found to strengthen the resistance towards contracting out in the EOD model (i.e. a negative coefficient at a $95 \%$ significance level, second column in Table 5), but it loses any significance when the time dependence of contracting out is taken into account (ETDOD model). A possible explanation for the weakness of the result is the steady decrease in electoral participation in Lombardy over the last decade, i.e. the passing of time is correlated to ElecPart. The health of the public budget has been modeled through FiscStress, which has never been found to be significant (all models, Table 5a). The negligible role of fiscal stress is in line with evidence offered in previous works on individual services (McGuire et al. 1987; Chandler and Feuille 1994; Walls et al. 2005; Miralles 2009). Most of the studies that have found a significant influence of fiscal restraints have in fact analyzed the whole service contract portfolio of local governments (Ferris 1986; Morgan et al. 1988; Kodrzycki 1998; Hebdon and Jalette 2008).

\subsection{Inter-municipal cooperation: Interaction with contracting out}

For the sake of brevity no comments have been made on estimates of the IMJV equation (Table 5b). Attention has instead been focused on the mutual relationship between contracting out and inter-municipal cooperation. Many papers have tried to compare them, and the estimates reported in this paper would allow such a comparison to be made. Nonetheless, the present sample and the peculiar context offered by the reform of the gas distribution sector in Italy have made it possible to estimate the two processes together, and to estimate the 
interdependence between them. The degree of interdependence is summarized by the Atanhrho_12 statistic, which is reported at the bottom of Tables $5 \mathrm{a}$ and $5 \mathrm{~b}$, i.e. a transformation of the correlation between the residuals of the two processes. This statistic is different from 0 and negative at a $1 \%$ level of significance. The result seems to suggest that the ex-ante preference of municipalities for one of the two restructuring measures is related to unobservable variables. In other words, inter-municipal cooperation does not cause, by itself, resistance to contracting out, but it would seem to suggest a different approach to service delivery. Contracting out offers the advantages of privatization, while inter-municipal cooperation keeps the service public and bestows a local identity on the service provision (Warner and Hebdon 2001; Hefetz et al. 2012). Local governments are likely to perceive these strategies as alternative and to choose their approach to restructuring on the basis of the relative costs and benefits, as measured by the coefficient estimates, and on a latent attitude.

\section{Conclusions}

This paper is an attempt to improve the understanding of the reasons why the diffusion of public service contracts in local governments appears to be slow and not to be able to challenge the dominance of public delivery, even when the restructuring experience is at an advanced stage. The degree to which public services are outsourced to the private sector is, of course, influenced by transaction costs, which vary greatly from country to country and sector to sector. However, a single-sector and single-country case can shed light on the additional motivations behind the fundamental reluctance of local governments to adopt contracting out. Therefore, we consider a reform that was introduced in 2000 in the Italian gas distribution. The efficiency of resistance has been assessed, and it has been found that municipalities are more likely to stick to public delivery if they are already exploiting scale economies, and have already reduced the discretion of public managers, by having corporatized the service 
operation. Beside the ideology of the government in power, other determinants, such as public budget restraints or the activism of citizens, are less likely to play an important role.

The present analysis adds new results and methods to the research on public service restructuring over a few dimensions. Not only does the paper confirm that the productivity of service provision is taken into account by local governments that have to choose the delivery mode, it also emphasizes the role played by the search for managerial efficiency, by modeling the governance of service provision in a comprehensive way. Moreover, the empirical approach shows that the empirical evidence can be strengthened in this field in three ways, i.e. using policy experiments as an empirical setting (as we did with the reform of the Italian gas sector), modeling the simultaneity of inter-municipal cooperation and contracting out decisions, and estimating the time dependence of restructuring decisions. All in all, the empirical results would seem to confirm that resistance towards contracting out can be consistent with a local governments' rational assessment of the incremental benefits and costs that arise from contracting out, and in particular with the search for efficiency.

The paper also leaves some research avenues open. A comprehensive test on the theory that the reluctance of a local government to contract out can be efficient requires a careful representation of the political patronage practices, i.e. the identification and measurement of city-level rather than state- or country-level indicators. Models should also encompass the spatial and temporal variations of price regulation and geographical aspects of the service, such as network deployment or the topology of served jurisdictions. Furthermore, empirical analyses of delivery choices should consider a wider set of restructuring measures, not just contracting out and inter-municipal cooperation, by taking into account the mutual interdependence between different strategies. Finally, greater attention should be paid to the diffusion of service contracts in European Union countries, through the construction and analysis of consistent cross-country datasets. 


\section{References}

Aivazian, V.A., Y. Ge, and J. Qiu. 2005. Can corporatization improve the performance of state-owned enterprises even without privatization? Journal of Corporate Finance 11(5): 791-808.

Amaral, M., S. Saussier, and A. Yvrande-Billon. 2009. Auction procedures and competition in public services: The case of urban public transport in France and London. Utilities Policy 17(2): 166-175.

Beck, N., J. N. Katz, and R. Tucker. 1998. Taking time seriously: Time-series-cross-section analysis with a binary dependent variable. American Journal of Political Science 42(4): 1260-1288.

Bel, G., and X. Fageda. 2009. Factors explaining local privatization: a meta-regression analysis. Public Choice 139(1-2): 105-119.

Bel, G., and X. Fageda. 2010. Partial privatisation in local services delivery: An empirical analysis of the choice of mixed firms. Local Government Studies 36(1): 129-149.

Bel, G., and A. Miralles. 2003. Factors influencing privatization of urban solid waste collection in Spain. Urban Studies 40 (7): 1323-1334.

Bel, G., and M. Mur. 2009. Intermunicipal cooperation, privatization and waste management costs: Evidence from rural municipalities. Waste Management 29(10): 2772-2778.

Bilodeau, N., and C. Laurin. 2007. Choice of organizational form makes a real difference": the impact of corporatization on government agency in Canada. Journal of Public Administration, Research and Theory 17(1): 119-147.

Bognetti, G., and L. Robotti. 2003. The Reform of Local Public Utilities in Italy. Annals of Public and Cooperative Economics 74(1): 117-137.

Bognetti, G., and L. Robotti. 2007. The Provision of Local Public Services through Mixed Enterprises: the Italian Case. Annals of Public and Cooperative Economics, 78(3): 415-437.

Boycko, M., A. Shleifer, and R. W. Vishny. 1996. A theory of privatisation. The Economic Journal: 309-319.

Boyne, G. A. 1998. Bureaucratic theory meets reality: Public choice and service contracting in US local government. Public Administration Review: 474-484.

Brown, T., and M. Potoski. 2003. Managing contract performance: a transaction cost approach. 
Journal of Policy Analysis and Management 2(2): 275-297.

Cambini, C., and M. Filippini. 2003. Competitive tendering and optimal size in the regional bus transportation industry: an example from Italy. Annals of Public and Cooperative Economics 74(1): 163-182.

Cambini, C., M. Filippini, M. Piacenza, and D. Vannoni. 2011. Corporatization and Firm Performance: Evidence from Publicly-Provided Local Utilities. Review of Law and Economics 7(1): 196-217.

Carrozza, C. 2010. Privatizing local public services: between industrial legacy and political ambition. Local Government Studies 36(5): 599-616.

Chandler, T., and P. Feuille. 1994. Cities, unions, and the privatization of sanitation services.Journal of Labor Research 15 (1): 53-71.

Dijkgraaf, E., R.H.J.M. Gradus, and B. Melenberg. 2003. Contracting out refuse collection. Empirical Economics 28(3): 553-570.

Dijkgraaf, E., and R.H.J.M. Gradus. 2008. Institutional developments in the Dutch waste-collection market. Environment and planning. C, Government \& policy 26(1): 110.

Dixit, A. 1997. Power of incentives in private versus public organizations. The American Economic Review 87(2): 378-382.

Domberger, S., and P. Jensen. 1997. Contracting out by the public sector: theory, evidence, prospects. Oxford Review of Economic Policy 13(4): 67-78.

Dorigoni, S., and S. Portatadino. 2009. Natural gas distribution in Italy: When competition does not help the market. Utilities Policy 17: 245-257.

Dubin, J., and P. Navarro. 1988. How markets for impure public goods organize: the case of household refuse collection. Journal of Law, Economics \& Organization 4(2): 217-241.

Erbetta, F., and L. Rappuoli. 2008. Optimal scale in the Italian gas distribution industry using data envelopment analysis. Omega 36(2): 325-336.

Ferris, J. 1986. The decision to contract out: an empirical analysis. Urban Affairs Quarterly 22(2): 289-311.

Fitch, K. 2007. Water privatisation in France and Germany: The importance of local interest 
groups. Local Government Studies 33(4): 589-605.

Greene, J.D. 1996. Cities and privatization: Examining the effect of fiscal stress, location, and wealth in medium-sized cities. Policy Studies Journal 24(1): 135-144.

Gonzalez-Gomez, F., and J. Guardiola. 2009. A duration model for the estimation of contracting out of urban water management in southern Spain. Urban Affairs Review 44(6): 886-906.

Gupta, N. 2005. Partial Privatization and Firm Performance", Journal of Finance 15: 987-1015.

Hebdon, R., and P. Jalette. 2008. The restructuring of municipal services: A Canada-United States comparison. Environment and Planning C: Government \& Policy 26(1): 144-158.

Hefetz, A., and M.E. Warner. 2007. Beyond the market versus planning dichotomy: Understanding privatisation and its reverse in US cities. Local Government Studies 33(4): 555-572.

Hefetz, A., and M.E. Warner. 2012. Contracting or Public Delivery? The Importance of Service, Market, and Management Characteristics. Journal of Public Administration Research and Theory 22(2): 289-317.

Hefetz, A., M. E. Warner, and E. Vigoda-Gadot. 2012. Privatization and intermunicipal contracting: the US local government experience 1992-2007. Environment and Planning-Part C 30(4): 675.

Hirsch, W. 1995. Factors important in local governments' privatization decisions. Urban Affairs Review 31(2): 226-243.

Hirsch, W. Z., and E. Osborne. 2000. Privatization of Government Services: Pressure-Group Resistance and Service Transparency. Journal of Labor Research 21(2): 316-326.

Joassart-Marcelli, P., and J. Musso. 2005. Municipal service provision choices within a metropolitan area. Urban Affairs Review 40(4): 492-519.

Johansson, T. 2008. Municipal contracting out: Governance choices, misalignment and performance in Swedish local government. Financial Accountability \& Management 24(3): 243-264.

Kodrzycki, Y. 1998. Fiscal pressures and the privatization of local services. New England Economic Review January/February: 39-50.

Levin, J., and S. Tadelis. 2010. Contracting for government services: Theory and evidence from US cities. The Journal of Industrial Economics, 58(3): 507-541.

López-de-Silanes, F., A. Shleifer, and R. Vishny. 1997. Privatization in the United States. Rand 
Journal of Economics 28(3): 447-471.

McGuire, R., R. Ohsfeldt, and T.N. Van Cott. 1987. The determinants of the choice between public and private production of publicly funded service. Public Choice 54(3): 211-230.

Ménard, C., and S. Saussier. 2000. Contractual choice and performance: the case of water supply in France. Revue d'Économie Industrielle 92(2-3): 385-404.

Miralles, A. 2008. The link between service privatization and price distribution among consumer types: municipal water services in the Spanish region of Catalonia. Environment and Planning C: Government \& Policy 2 6(1): 159-172.

Miralles, A. 2009. A duration model analysis of privatization of municipal water services. Rivista de Economia Aplicada 17(50): 47-75.

Morgan, D., M. Hirlinger, and R. England. 1988. The decision to contract out city services: a further explanation. Western Political Quarterly 41(2): 363-372.

Morgan, D. R., and M. W. Hirlinger. 1991. Intergovernmental Service Contracts: A Multivariate Explanation. Urban affairs review 27(1): 128-144.

Nemec, J., B. Merickova, and L. Vitek. 2005. Contracting out at local government level. Public Management Review 7(4): 637-647.

Roodman, D. 2009. Estimating fully observed recursive mixed-process models with cmp. Center for Global Development Working Paper 168.

Savas, E. 1987. Privatization: the key to better government. Chatham, NJ: Chatham House Publishers.

Shleifer, A., and R. Vishny. 1994. Politicians and Firms. Quarterly Journal of Economics 109(4): 9951025.

Sørensen, R. J. 2007. Does dispersed public ownership impair efficiency? The case of refuse collection in Norway. Public Administration 85(4): 1045-1058.

Stiglitz, J.E. 2000. Economics of the Public Sector, 3rd edition. Norton Press.

Tavares, A. F., and P. J. Camöes. 2007. Local service delivery choices in Portugal: A political transaction costs framework. Local Government Studies 33(4): 535-553.

Walls, M., M. Macauley, and S. Anderson. 2005. Private markets, contracts, and government provision. What explains the organization of local waste and recycling markets? Urban Affairs 
Review 40(5): 590-613.

Warner, M. E. 2011. Competition or cooperation in urban service delivery?.Annals of Public and Cooperative Economics 82(4): 421-435.

Warner, M.E., and G. Bel. 2008. Competition or monopoly? Comparing privatization of local public services in the US and Spain. Public Administration 86(3): 723-735.

Warner, M.E., and R. Hebdon. 2001. Local government restructuring: Privatization and its alternatives. Journal of Policy Analysis and Management 20(2): 315-336

Warner, M. and A. Hefetz. 2002. Applying market solutions to public services: an assessment of efficiency, equity and voice. Urban Affairs Review 38(1): 70-89.

Warner, M. E., and A. Hefetz. 2004. Pragmatism over Politics: Alternative Service Delivery in Local Government, 1992-2002. The Municipal Year Book 2004: 8-16.

Warner, M. E., and A. Hefetz. 2008. Managing markets for public service: the role of mixed publicprivate delivery of city services. Public Administration Review 68(1): 155-166.

Williamson, O.E. 1981. The economics of organization: the transaction costs approach. The American Journal of Sociology 87(3): 548-577.

Williamson, O.E. 1999. Public and private bureaucracies: a transaction cost economics perspective. Journal of Law, Economics \& Organization 15(1): 306-342.

Yvrande-Billon, A. 2006. The attribution process of delegation contracts in the French urban public transport sector: why competitive tendering is a myth. Annals of Public and Cooperative Economics 77(4): 453-478.

Zullo, R. 2009. Does fiscal stress induce privatization? Correlates of private and intermunicipal contracting, 1992-2002. Governance 22(3): 459-481. 


\section{Appendix}

Table A1 - Distribution of new service contracts over municipal services, 8 largest EU countries

\begin{tabular}{|l|ccc|}
\hline Services & $\begin{array}{c}2009-2011 \text { count of new } \\
\text { service contracts } \S\end{array}$ & $\begin{array}{c}\text { Average yearly } \\
\text { growth rate }\end{array}$ & $\begin{array}{c}2009-2011 \text { count per } \\
10,000 \text { inhabitants } \#\end{array}$ \\
\hline $\begin{array}{l}\text { Sewage, solid waste and } \\
\text { cleaning services }\end{array}$ & 6,281 & $4.4 \%$ & 0.16 \\
$\begin{array}{l}\text { Health and social work } \\
\text { services }\end{array}$ & 2,480 & $5.1 \%$ & 0.06 \\
$\begin{array}{l}\text { Gardens and parks } \\
\text { maintenance }\end{array}$ & 1,695 & $0.8 \%$ & 0.04 \\
$\begin{array}{l}\text { Public transport services } \\
\text { Streets and roads }\end{array}$ & 1,179 & $-5.5 \%$ & 0.03 \\
maintenance & 929 & $-2.5 \%$ & 0.02 \\
Public utility services & 321 & $24.3 \%$ & 0.01 \\
Public security services & 203 & $-2.4 \%$ & 0.01 \\
Cultural and sporting & 453 & $-14.4 \%$ & 0.01 \\
services & 13,249 & $3.1 \%$ & 0.34 \\
\hline 8 largest EU countries & & & \\
\hline
\end{tabular}

Source: Online supplement of the Official Journal of the European Union (so called "Tenders Electronic Daily"). Notes. §: Contract notices have been drawn and classified with a focus on local and regional authorities as contract sources. Only municipal services have been considered, i.e. those public services that are under the responsibility of municipalities, according to the census of local governments prepared by the Council of European Municipalities and Regions. A detailed classification is available upon request from the authors. \#: The number of EU inhabitants was equal to $502,120,829$ in $2011^{\wedge}{ }^{\wedge}$ : The sums by services and by countries are different, because some contract notices pertained to more than one service class. The EU largest countries are: Germany, France, The United Kingdom, Italy, Spain, Poland, Romania and the Netherlands.

Table A2 - Distribution of new service contracts over largest EU countries, municipal services

\begin{tabular}{|l|ccc|}
\hline Countries & $\begin{array}{c}2009-2011 \text { count of new } \\
\text { service contracts } \S\end{array}$ & $\begin{array}{c}\text { Average yearly } \\
\text { growth rate }\end{array}$ & $\begin{array}{c}2009-2011 \text { count per } \\
10,000 \text { inhabitants } \#\end{array}$ \\
\hline France & 4,980 & $1.5 \%$ & 0.77 \\
The Netherlands & 766 & $-1.6 \%$ & 0.46 \\
Italy & 2,379 & $10.5 \%$ & 0.39 \\
The United Kingdom & 2,118 & $-4.5 \%$ & 0.34 \\
Poland & 1,071 & $11.6 \%$ & 0.28 \\
Spain & 673 & $-5.8 \%$ & 0.15 \\
Germany & 1,117 & $12.0 \%$ & 0.14 \\
Romania & 145 & $-2.7 \%$ & 0.07 \\
\hline 8 largest EU countries ${ }^{\wedge}$ & 13,249 & $3.1 \%$ & 0.34 \\
\hline All EU countries & 15,788 & $4.2 \%$ & 0.31 \\
\hline
\end{tabular}

Source: Online supplement of the Official Journal of the European Union (so called "Tenders Electronic Daily"). Notes. §: Contract notices have been drawn and classified with a focus on local and regional authorities as contract sources. Only municipal services have been considered, i.e. those public services that are under the responsibility of municipalities, according to the census of local governments prepared by the Council of European Municipalities and Regions. A detailed classification is available upon request from the authors. \#: The number of EU inhabitants was equal to $502,120,829$ in $2011^{\wedge}{ }^{\wedge}$ : The sums by services and by countries are different, because some contract notices pertained to more than one service class. The EU largest countries are: Germany, France, The United Kingdom, Italy, Spain, Poland, Romania and The Netherlands. 
Table A3 - Distribution of the sampled municipalities over provinces and population ranges

\begin{tabular}{|l|ccccc|}
\hline Province & $<5,000$ & $5,001-15,000$ & $15,001-50,000$ & $>50,000$ & Total \\
\hline Bergamo & 18 & 11 & 2 & 1 & 32 \\
Brescia & 0 & 5 & 3 & 1 & 9 \\
Como & 0 & 4 & 2 & 1 & 7 \\
Cremona & 7 & 4 & 1 & 1 & 13 \\
Lecco & 0 & 2 & 1 & 0 & 3 \\
Lodi & 2 & 3 & 1 & 0 & 6 \\
Milan & 4 & 14 & 13 & 3 & 34 \\
Mantova & 2 & 3 & 1 & 0 & 6 \\
Monza & 1 & 2 & 10 & 1 & 14 \\
Pavia & 0 & 2 & 1 & 2 & 5 \\
Sondrio & 0 & 0 & 1 & 0 & 1 \\
Varese & 0 & 2 & 1 & 2 & 5 \\
\hline Total & 34 & 52 & 37 & 12 & 135 \\
\hline
\end{tabular}

Source: National Institute of Statistics 